\title{
Traditional Curry Pastes During Sukhothai to Ratthanakosin: The Subjective Experience of the Past and Present
}

\author{
Taddara Kanchanakunjara ${ }^{1,2,3}$, Songkoon Chantachon ${ }^{2}$, Marisa Koseyayothin ${ }^{2} \&$ Tiwatt Kuljanabhagavad $^{3}$ \\ ${ }^{1}$ School of Culinary Arts, Suan Dusit Rajabhat University, Bangkok 10700, Thailand \\ ${ }^{2}$ Faculty of Cultural Science, Mahasarakham University, Mahasarakham 44000, Thailand \\ ${ }^{3}$ Bioorganic Chemistry Research Laboratories, Faculty of Science and Technology, Suan Dusit Rajabhat \\ University, Bangkok 10700, Thailand \\ Correspondence: Tiwatt Kuljanabhagavad, Bioorganic Chemistry Research Laboratories, Faculty of Science and \\ Technology, Suan Dusit Rajabhat University, Bangkok 10700, Thailand. E-mail: ktiwatt@gmail.com
}

\author{
Received: September 16, 2014 Accepted: September 26, 2014 Online Published: November 10, 2014 \\ doi:10.5539/ach.v7n1p175 \\ URL: http://dx.doi.org/10.5539/ach.v7n1p175
}

\begin{abstract}
Although there are numerous studies about the traditional curry pastes and Thai food uses claims about the historical development can be divided into nine eras. The research has explored traditional curry pastes' perceptions of such features and how these might relate to religion and a royal court. Perceptions of curry pastes are influenced by individual and societal factors, local raw materials, and raw materials along the trade routes. Thai food has been influenced by Indian curry and Chinese stir frying techniques. In fact, traditional curry pastes and Thai food has its own culinary style. The traditional curry paste in Sukhothai to Ratthanakosin is heavily influenced continued by religion and a royal court. Traditional curry paste usually contains fresh light flavors of lemongrass and kaffir lime skin and the soothing effect of coconut cream and coconut milk. The spice ingredients are used in curry paste may differ from home to home or region to region. The delicious spicy and hot Thai foods with a traditional blend of aromatic flavors are popular in the world. Usually Thai people eat three times a day includes meat, salads, soup, noodles, curry, and rice. All the recipes are in the collection of original Thai dishes such as a popular curry and also other curries traditionally processed Thai curry paste products named massaman curry called gaeng massaman and well known of hot and sour soup called tom yum.
\end{abstract}

Keywords: traditional knowledge, curry paste, massaman curry, tom yum, functional food, Thai food

\section{Introduction}

Thai food and traditional curry paste is the most complex and refinement food in Asia and this reflects presence of religion and a royal court which encouraged the culinary arts, considerable regional diversity and a board spectrum of ingredients. (Hazra, 1982; Kulke \& Rothermund, 1998; Rajadhon, 1988). Although the royal Thai government promised at the global community summit in the year 2003 to 2027 on food and agriculture for industry kitchen of the world, the situation has continued until now. In Thailand, a way of living of the people at household in several forms reflecting the relative status of those involved the temples. Buddhism may be broadly classified into these two sects, Theravada and Mahayana (Hazra, 1982). Theravada Buddhism practiced by most Thai people does not prohibit or discourage the eating of meat except as a voluntary practice. Thailand is the country of 513000 square kilometers situated on the Indochina peninsula in Southeast Asia (Kosulwat, 2002). The population is approximately 65 million in the year 2014 (Prasartkul \& Vapattanawong, 2012). Thailand is one country of the world's greatest producers of high quality jasmine rice, having three to four harvests annually. In generally, jasmine rice (or khao hom mali) is grown in Ayutthaya province and other province is preferred in north, northeast, east, and central Thailand. Sticky rice is preferred in the northeast and north of Thailand. Thai meal consists of Thai jasmine rice, soup, salad, a steamed, fried, stir fried or grilled dish, a spicy vegetable and fish dish, curry, condiments, dessert and fruit served at the same time and in no particular order. History of the original curry pastes was found during the $13^{\text {th }}$ to $21^{\text {st }}$ centuries and this tendency continued as a general framework for the original Thai curry pastes during Sukhothai to Ratthanakosin. This study aims to acquire the knowledge about the type of geang and taste active components in curry paste, and classification of traditional curry pastes, and historical development of curry paste, and curry paste in Sukhothai to Ratthanakosin, and this study is based on main sources especially the historical source and other sources used in writing the paper and that is the book and article. 


\subsection{The Type of Geang in Thailand}

Thai word for curry called geang (or keang) in sometimes written geng (or gang or kang) usually means any wet savory dish enriched and thickened by a paste. The point of view is an aromatic curry paste either made at home or purchased. The curry paste ingredients are pounded together in a stone mortar and pestle which allows the release of the essential oil in the tissue of Thai herb and spices that impart flavor and fragrance. The followed preparing curry pastes can take twenty minutes to half and hour for a daily meal. In addition, the traditional foods in Thai style are placed in dishes and these again are arranged in a tray. The original Thai food has become very popular, even crossing over to mainstream menus. Thai food is a unique combination of royal Thai elaborate presentation, Indian influenced curries. In fact, a traditional curry paste has its own culinary style with ethnic Thai ingredients such as galangal, lemongrass, and fragrant basils. Moreover, the original Thai foods are emerging as the significant cuisine and a regional flavor such as massaman curry, red curry, green curry, and the well known of hot and sour soup as tom yum and yellow curry (or geang hleung) can be usually found in the southern Thailand.

\subsection{Taste Active Components in Traditional Curry Pastes}

In Thailand, curry pates are contained shrimp paste in Thai word called gapi or kapi made from tiny shrimp that are marinated in salt, dried in the sun, pulverized and fermented for several months. Kapi is a typical fermented shrimp and commonly used in traditional Thai food. It was consumed extensively as a condiment in every region of Thailand (Faithong et al., 2010). It is mainly ingredient used for flavoring dished and in various spicy soups in original Thai food (Chotechuang, 2012). There are different forms of Thai curry depend on types of num prik. Num prik may be roasted on chillies, ginger, garlic, kapi, lime juice, and sugar (palm sugar or cane sugar) is combined to make one of the most typical in every region of Thailand. The central region of Thailand increased their consumption of sugar and sweeteners more than other regions. Thai fish sauce (or nam pla) is used in traditional curry pastes and Thai dishes. Nam pla is a common name of fish sauce can be found in every region of Thailand. Nam pla is used as an active component in almost Thai dishes. Fish sauce is usually known in many countries of Southeast Asia such as tuk trey in Cambodia, bakasang in Indonesia, ngan-pya-ye in Myanmar, nuoc mam in Vietnam, and nam pla in Thailand (Mouritsen, 2012; Yoshida, 1998).

\subsection{Classification of Traditional Curry Pastes}

Thailand is rich in food resources, and the use of locally available ingredients has thus become a main feature of traditional curry pastes. The classification of traditional thai curries are yellow curry, massaman curry, gold curry, green curry, red curry, panang, and jungle curry. Curries are the richest dish of Thai food being based on herbs and spices and different combinations of meats, fish, vegetables, and fruits. It is mostly used a variety of ingredients from local sources such as chili peppers, kaffir lime leaves, lemongrass, galangal and coconut milk, the flavors as a result of Thai curries tend to be more aromatic than Indian curries (Raghavan, 2007). All of Thai dishes were excellent, large, and authentic in taste. The curries in Thai foods are categorized by the methodology of the paste used in their preparation method. It is normally described by color, for instance red curries use red chillies and green curries use green chillies as the essential ingredients. Yellow curry is called gaeng curry (or geang kari) of which a word-for-word translation would be soup curry. Yellow curries in Thai food are more similar to Indian curries, with their use of turmeric rhizomes and cumin fruit as the important ingredients. Furthermore, yellow curries (or geang hleung) in Thailand country usually do not contain potatoes except in some Thai style cooking of south Thailand and Thai restaurants abroad usually have them. The curries are either water-based or coconut-milk-based. Coconut-milk-based curried are prevalent in Bangkok and the central region of Thailand. Water-based curries are more common in north Thailand.

\subsubsection{Red Curry}

Red curry paste includes dried red chillies, peppercorns and lime zest, and sometimes roasted and ground Indian spices such as coriander, cumin, and cloves. A popular Thai dish of red curry was used of red chili as a color name in Thai based on coconut milk heated with red curry paste and nam pla. Red curry is usually compared to the Indian Sambar. It is used mixture of almost any kind of meat, fish or vegetable. Red curry dishes were included the important ingredients of kaffir lime leaves, pea eggplant, Thai eggplant, coconut milk, Thai basil, and some sort of meat such as beef, chicken, fish, duck, pork or shrimp. Thai red curries have plenty of chilli sauces which is salty sweet and can be quite fiery hot. In some place of central and south Thailand more added the local ingredient of bamboo shoots, young coconut stem and the product of season.

\subsubsection{Green Curry}

Green curry paste originating in Asia has been changed to suit the taste of every adoptive palate. In the $13^{\text {th }}$ century, Siam opened up to trade during the Ayutthaya period the Indian and Moorish peoples were said to have added milk 
and creams and later, coconut milk, to a basic paste of coriander fruit and root, cumin, peppercorns, lemongrass, kaffir lime skin, garlic, shallots, and shrimp. Green curry made from fresh spices and fragrant plant of cumin (Siripongvutikorn et al., 2008). Coriander roots and stems are chopped and used as an ingredient in Thai dishes. Green curry is indispensable ingredients in Thai green curries and green dish using green chili peppers. Green curries paste combined with strongly flavored fish, meat or bitter vegetables that contains fresh green chillies, basil leaves, lime leaves, pea eggplant, and round Thai eggplant. A basic green curry includes green chilies, coriander, kaffir lime leaves, shallot and rinds, lemongrass, garlic, cumin, and nam pla. The dish has citrus undertones and can be mild or hot. Green curry likes all curry blends varies in composition and flavor depends on the cook different in the regions.

\subsubsection{Massaman Curry}

A long history of traditional curry paste of massaman curry paste was found in the $13^{\text {th }}$ century. In thirteenth century, Islam spread to Southeast Asia via the maritime trade routes that connected India with the spice islands of the East (Kulke \& Rothermund, 1998). The first time, massaman curry found in the $14^{\text {th }}$ century of Lanna Kingdom (Pelliot, 1959). The Chiang Mai was capital of the Lanna Kingdom was found in the year 1296 by the first King Mengrai of Mengrai dynasty (Manich, 1967) and annexed by Siam in the year 1892. It was established in the same time as the Sukhothai Kingdom establishment in the year 1157. The ethnic Lanna people live mainly in the north of present-day Thailand. The word of Lanna is actually two words combined Lan and Na meaning a million rice fields (Cochrane, 2008; Manich, 1967). Massaman curry paste is made with beef, lamb or pork, originated a Thai dish that is Muslim in origin using Portuguese spicing. The information knowledge is supported the massaman curry paste with the cumin originated on the Mediterranean region (Douglas et al., 2005). The cumin is alway used in massaman curry. The name of massaman (singular noun) is thought to be derived from the word of musulman (plural noun) the word the meaning of Islamic or Muslim (Grove \& Grove, 2010). The massaman curry paste was suggested a regular "massaman" singular word. They are have been used of the differ ingredients in the massaman curry. Massaman curry is a blend of traditional Thai and Indian curries and usually contains coconut milk, roasted peanuts, potatoes, bay leaves, cardamom pods, cinnamon, palm sugar, tamarind sauce, and nam pla. It is commonly made with beef in Thai langue named gaeng massaman. In the southern Thailand, three provinces are large Muslim population near the Malaysian border such as Yala, Pattani, and Narathiwat. The original paste contains dried red chillies ground coriander, cumin, cloves, white pepper, peanuts, and unusual for a Thai curry roasted whole spices such as cinnamon, cardamom, and nutmeg.

\subsection{Tom Yum}

The most famous hot and sour soup of Thai dishes is tom yum thought out around the world. Tom yum is typically characterized by its distinct hot and sour flavors with aromatic herbs and spices generously used. The basic broth is made of stock and fresh ingredients such as galangal, kaffir lime leaves, lemongrass, lime juice in combined nam pla, and crushed bird's eyes chili with prawns or goong. Tom yum gai uses chicken instead often called the signature dish of Thailand (Kanchanakunjara, 2008; Kanchanakunjara, 2013).

\subsection{Thai Herbs and Spices in Kitchen}

Many of the plants are also available and found in the kitchen such as clove, cardamom, cinnamon, coriander, cumin, galangal, garlic, kaffir lime, lemongrass, nutmeg, chili, shallot, star anise, and white pepper. Traditional ingredients of Thai curry paste has different type and content of the material. Herbs and spices are commonly used in traditional curry paste as in Thailand may differ from home to home or region to region. The system of holistic curry pates known of Thai curry paste is mainly use herbs and spices-based materials or formulations to authentic curry paste various ailments such as massaman curry, green curry, geang som, red curry, tom yum, and red curry consist of red chili, shallot, garlic, lemongrass, galangal, kaffir lime leaves, shrimp paste and salt. Dried chilies (or fresh chilies) are used in curry pastes and Thai salads for many dishes. Massaman curry usually consists of dried red chili, shallot, garlic, lemongrass, galangal, kaffir lime skin, cumin, white pepper, shrimp paste, and salt. Green curry usually consists of green chili, shallot, garlic, lemongrass, galangal, and kaffir lime skin. Geang som consists of dried red chili, shallot, garlic, lemongrass, shrimp paste, and salt. Thai curry is the most important materials of herbs and spices related to types of Thai dishes such as red curry, green curry, massaman curry, panang curry, and tom yum. Tom yum consists of lemongrass, galangal, red chili, shallot, and kaffir lime leaves (Kanchanakunjara, 2013).

Functional food is demonstrate positive effect and no negative effects from on health beyond basic nutrition. Plant and plant products are being used as a source of medicines for a long time. Plant products have been used throughout human history for various purposes. Tens of thousands of them are produced as secondary metabolites by the higher plants consist of monocots and dicots as a natural defense against disease and infection. For herbs and spices are important plant products in high vitamin, nutrition component, and phytonutrients. Phytonutrients 
and vitamins are contents secondary metabolites produce by plants. Plant products are mixtures of chemical compounds that are used to flavor or season food. They are aromatic compound, monoterpenoids, sesquiterpenoids can be found in the aromatic dried plant products. Spices are include all aromatic dried of different plant products such as arils, barks, flower buds, fruits, leaves, rhizome, and other parts of woody plants such as climbers, shrubs, and trees. Thai curry paste is made from herbs and spices that a source of natural products contain of various natural compounds. The herbs and spices are classified as natural preservative agents because of the active compounds in their plants provide inhibit bacterial and fungal growth such as curcumin in the rhizome of Curcuma longa L. shows a wide range of pharmacological properties including antimicrobial, antioxidant, anti-inflammatory, and anticancer (Miquel et al., 2002). Allicin in the garlic (Allium sativum L.) is the most active compound showed antimicrobial activity. This compound was found to exhibit antibacterial activity against gram-negative and gram-positive bacteria that included multidrug-resistant enterotoxicogenic strains of Escherichia coli, antifungal activity such as Candida albicans. In Thailand, the rhizome of galangal (Alpinia galangal L.) is used for medicinal purposes such as stomachic, carminative, antispasmodic, antichloristic, and antibacterial drugs, and as an antioxidation. Capsaicin in the chilies (Capsicum frutescens L.) is the major compound that can inhibit the growth of Helicobacter pylori (Jones et al., 1997). According to Seah et al. (2010) to studies found that the combination of herbs and spices and its gradient used in the yellow curry or geang hleung paste was turmeric rhizome, garlic, chili and galangal shows significant antioxidant and antibacterial as natural preservatives and functional food (Kuljanabhagavad et al., 2014; Seah et al., 2010). The role of natural products in human healthcare cannot be underestimated. An estimated $80 \%$ of individuals in developing countries depend primarily on natural products to meet their healthcare needs (Goel et al., 2008). Medicines derived from plants have played a pivotal role in the health care of many cultures, both ancient and modern. The system of holistic medicine known as Thai Traditional Medicine (TTM) uses mainly plant-based drugs or formulations to treat various diseases.

They are classified into part of the two kinds of nutrition chemical compounds and non-nutrition chemical compounds. The nutrition chemical compounds are vitamins and the mineral element compounds while non-nutrition chemical compounds are secondary metabolites that produce by plants in the nature. Since the beginning of civilization, food plants, herbs, and spices have been used by humankind for its multiple values dependent on plants for their health care needs. The source of phytochemical compounds can be links to the effective of the individual compounds and mixture compounds of the natural product of herb and spices. Chili is a characteristic red color due to the presence of red-pigmented carotenoids and a good source of carotenoids. Turmeric has a characteristic yellow color due to the presence of curcuminoids. The aromatic plant is due to the volatile oils present to the extent of 1.80-2.49\% in dry turmeric (Kuljanabhagavad et al., 2014). The plants contain essential oil widely used in food, drink, body care products, soap, perfumery, and pharmaceutical products (Wei \& Wee, 2013). The fruits and rhizomes of galangal have a pungent smell. Two common spices of citronella grass (Cymbopogon nardus Rendle) and lemongrass (C. citratus (DC) Stapf.) are native herbal plants. For the main compounds or major constituents can be found in the higher yield in the herb and spices. For instant, garlic one of the ingredients in massaman curry and other curries have been reported to possess allicin, a highly active volatile constituent showed the antimicrobial activity (Ankri \& Mirelman, 1999).

\section{Historical Development of Traditional Curry Paste}

Thai food has been a product of transnational interactions for long periods during $6^{\text {th }}$ and $11^{\text {th }}$ centuries of Dvaravati Kingdom influence of Indian culture (Sirivejkul, 2003). The original Thai traditional cooking most people believed in the uniqueness. In the $15^{\text {th }}$ century, Khmer cooks introduced Indian food pattern such as many curries and boiled red and white sweets until the Ayutthaya's court during the $14^{\text {th }}$ to $18^{\text {th }}$ century. Nam pla is a condiment and crucial ingredient in every Thai dish. In the $16^{\text {th }}$ century, Portuguese were introduced chilies to traditional curry paste and in combination with nam pla, galangal, and kaffir lime; they give a distinctive aromatic and taste to Thai dishes. In earlier $17^{\text {th }}$ century contact with Western cultures a Thai dessert modified from Portuguese dish left a culinary legacy of Kanom thong yip.

There is evidence of human habitation for some curries past in Thailand for long time state starting in Sukhothai period (1157-1438 A.D.) and Ayutthaya as capital (1350-1767 A.D.) and its succession of Kings both weak and strong, endured for 417 year and came to end in the year 1767 through a ware with Myanmar. One of the generals of the last King of Ayutthaya, known vulgarly as Phya Tak Sin, succeeded by an heroic effort in driving the enemies out of the country. He became a King of Thailand but moved the capital from Ayutthaya, which by now was in ruins and depopulated, to Thonburi (1767-1782 A.D.), a city on the right bank of Chao Phya River of the present greater city of Bangkok. King Rama I of the present Chakri dynasty succeeded King Tak Sin in the year 1782 (Ratthanakosin period, 1782-present) (Sirivejkul, 2003). In order to understand the traditional curry paste 
and a food of a state, it is necessary to trace back different eras of history of that state. A long history of Thai traditional curry paste begins 817 years; Sukhothai was one of the early Kingdoms in Thailand emerged integrating traditional muang administration with the Indian mandala concept of the centralized state. In spite of influences from India, Sri Lanka, and neighboring regions, Sukhothai evolved its own in the realm of language, script, and religion that become an essential function part of Thai culture. Traditional curry paste today and Thai food is an essential part that was combination of indigenous curry paste and the influence of Indian and Chinese culinary traditions. Thai curry paste that involved in Sukhothai period was similar to traditional ingredients with the presence of a curry paste of massaman curry.

\subsection{Traditional Curry Paste in Sukhothai Period}

During the Sukhothai period was an important commercial center and various civilization centers in food and eating. It was the beginning of notes in Traipoom Pra Ruan Og Prayalithai description of Sukhothai as capital. Sukhothai period became capital at that time, Siamese and Siam had been a part of land of Southeast Asia. Thai food has been reported for long time history starting with Sukhothai as capital have been found in the Sukhothai stone (Bradley, 1909; Frankfurter, 1906; Rajanubhab, 1914-15). In that time, the word U may be translated as a cradle or as an origin. That the reason we speak of $U$ Nam origin of water, and of $U$ Khao origin of rice, as the two necessaries of life for founding a settlement (Heide \& Homan, 1906; Rajanubhab, 1904). The starting point of the presence of a water monitor wasting the curry stated that after King Ramkhamhaeng (Gerini, 1904). In the early $13^{\text {th }}$ century, from the historical records in King Ramkhamhaeng's famous stone inscription, it is clear that rice and fish as the major ingredients of Thai food. The origin of the Thai diet begins with the waterborne community. They are consistent with the traditional Thai eating pattern. Thai culture developed under Rama Khamheng's reign in Sukhothai period. In that time, the Aquatic animals, plants, and herbs are used. They are used a great deal in preparing meals; large pieces of meat are rarely used in any dish. The common cooking methods are widely practiced still used stewing, grilling, baking, and frying. The fresh herbs and spices are common ingredients in the most of Thai dishes. Thai meals (or Thai dishes) are not served in courses instead of, they are served at the same time allowing the various dishes to complement and enhance each other. Thai food recipes are eaten with rice which is the main dietary staple for Thai population.

\subsection{Traditional Curry Paste in Ayutthaya Period}

In the year 1279 of King Ramkhamhaeng has been reported people in everywhere growth various plants such as rice, coconut groves and groves of land, mangoes, palm trees, groves of betel and tamarinds for used in the household (Bradley, 1909; Coedes, 1918). The starting point of Ayutthaya period in the year 1350, King Uthong set up Ayutthaya as capital. King Nareasuan the great of Ayutthaya period become both in the commercial center and to foreign country contains within itself one of the most rich and diverse sources of resources on the world. In a small area have rice plains and rich in spices and medicinal products but rare animals and yielded valuable metals on mountains, and all manner of inlets and outlets (Wright, 1992). In the great King Narai in the year 1685 was the center of the best chefs who cooked Chinese, France, Japanese, Persian, and Portuguese (Coedes, 1921; Wyatt, 1974). In the reign of Narai, Portuguese brought chili with them then chili was included in many ingredients of cooking to add more spicy taste. In Ayutthaya period, they are used pepper not chili as ingredient in spicy curry cooking as chili was not appearance in the local. Massaman curry is a spicy curry, which is adopted from foreign civilization. It is presumed cooked by Indian chef who was noted by Persian Ambassador that King Narai was the only one who liked the rich Indian food. In his reign, Indian chef who cooked Indian food was directly involved Thai foods in the Royal kitchen. Massaman dish is the Bunnag's popular dish. Chekahmed-the Persian business people worked in the Royal Institute who adapted Thai Muslim food by using milk (or yogurt) instead of coconut cream. Japanese stew types using coconut oil and coconut cream in there cooking.

\subsection{Traditional Curry Paste in Thonburi Period}

The original Thai food in Thonburi period was similar to Ayutthaya period especially Chinese food. Beyond this period, though there historical records, especially of Thai people of north Thailand, Laos, and the Shans, we enter comparatively into the realm of myths and legands with exaggerated dates for self-glorification-a thing to be found in a nation's history. Thonburi as a capital became the greater city of Bangkok in the present. It is the longest official name in the world an abbreviated from is Krung Thep Maha Nakhon which means the capital city of gods. The important information of this period, the first Thai cookbook Mae Krua Hu Pra in Thonburi period wrote by Thanpuying Plien Paskornwong showed that continue of cooking food captured from the Sukhothai to Ayutthaya and during Thonburi to Ratthanakosin period through government duties and family society. 


\subsection{Traditional Curry Paste in Ratthanakosin}

\subsubsection{The reigns of King Rama I to King Rama III}

In Ratthanakosin kingdom should be divided of two section of King Rama I to King Rama III and King Rama IV to King Rama IX; in the section 1 (1782-1851). In the reign of King Rama I, as the same time in Ayutthaya period there are many contacts with foreign countries through commercial and ambassador and become the commercial center. There is civilization development, which included the cooking. Thai ladies who cooked delicious food were praised of having "Spoon tip charming" Thai spicy curry dishes are popular, cooked in every home, every time and every function. During King Somdet Phra Narai of Ayutthaya period from 1656 to 1688 has reported Maria Guyomar de Pinha or Thao Thong Kip Ma in Thai. She is a Japanese-Portuguese lady and was born in Thailand and worked in the palace's kitchen where she was responsible in making food for the royal family and their foreign guests and the French ambassadors. She has a creative dessert recipe that was adapted from Portuguese culinary influence with the using of local ingredients of coconut cream, rice flour, and sugar. Spicy curry was included in the royal function as recorded in letter on the renovation of the Temple of The Emerald Buddha 1982 Navinthevi's dairy. In the reign of King Rama II could be regarded as one of relative peace. It was a period of consolidation in which the people of Siam could pause and reflect upon the hectic changes and achievements of the previous reign. Thai food in this period is influenced by palace people to make good quality of Thai food with delicately carving vegetables and fruits. The spicy curry was included in many writing for example, boat song writing about food and desserts. There were 15 kinds divided to 4 kinds of spicy curry dished. For instant, massaman curry, thea po, geang khom, and geang krau som cooked by ladies or ladies in the palace who cooked carefully and tasty named "Palace type" and "Royal dishes". King Rama II's writing on "Sang Thong" about Gaeng Fak. A literature "Khun Chang and Khun Pann" about food from birth untill die reflected the local female helping each other to cook Panang spicy curry for monks and company. In the reign of King Rama III, closed contact with China. New Year celebration and making merit, the food included Khanomjeen to the monks, staffs mean the long life, and served together with nam ya curry dishes.

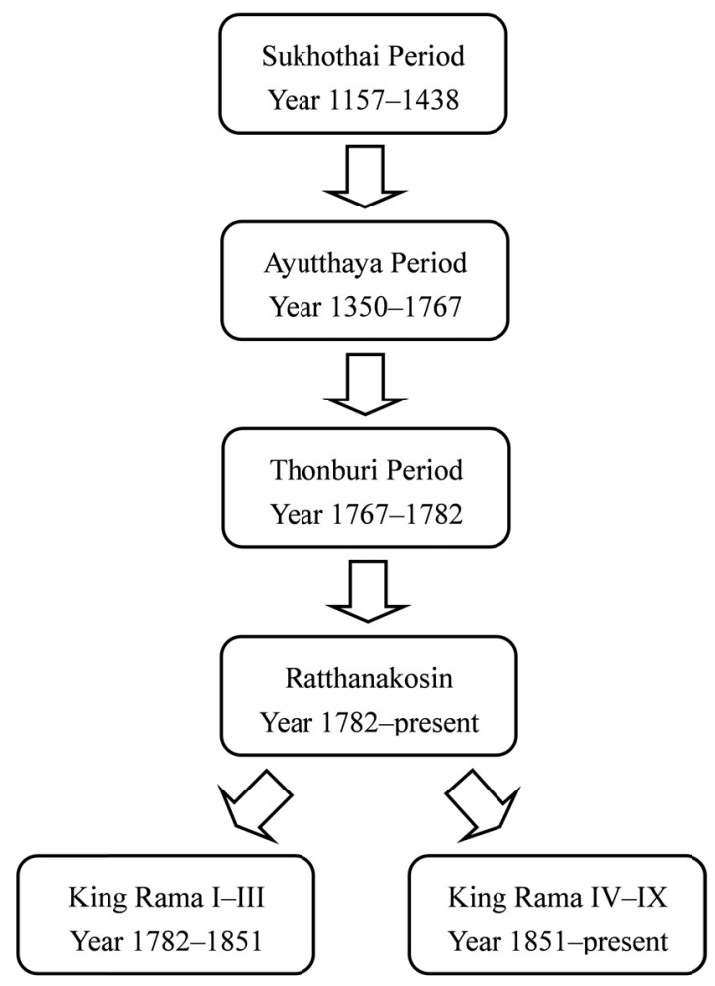

Figure 1. The original curry dishes development from Sukhothai continued to Ratthanakosin

\subsubsection{The reigns of King Rama IV to King Rama IX}

The section two (1851-present) at the reign of King Rama IV, for this reason, in King Rama IV is dynamic and complex influence from the western culture. The first Thai food textbook called Mae Krua Hu Pra wrote by Thanpuying Plien Paskornwong. The third month ceremony Chinese New Year, included in the ceremony of 
making merit were spicy curry use baked chilli as an ingredient cooked by Choom, one of King Rama IV's wife Prince Damrong's mother. In the reign of King Rama V, there were a lot of changes of food development as to international development by Assistance Prof. Dr. Winai Dalan wrote in "Food Nutrition: to follow King Rama V's foot step "refer to Polsri Kachacheewa who summarized geang pla or chicken curry without coconut cream but when Thai people like coconut cream they cooked spicy curry with coconut cream until the end of the reign the name of spicy curry with coconut cream was call spicy curry. The spicy curry or chicken curry cooked without coconut cream called a jungle curry. A jungle curry is a country curry that is simple and robust in flavor and technique. Lady Plien's first Thai food textbook also called "A jungle curry chef". In the reign of King Rama VI the Thai food in the palace was described in the Boat song that chicken curry mixed with Chinese noodle was similar to the food in the reign of King Rama V in decoration, color, flavor, and taste. In the reign of King Rama VII, the popular food was simple to cook, boil, fry, cook the meat overnight, and prepare to add ingredient next morning. Spicy curry will be prepared in the evening and add in the vegetable the next morning, as there was no refrigerator available for the normally people. In the reign of King Rama IX is the most complex of Thai food in the country and has other food from some country such as Japan, South Korea, and Vietnam.

During the Ratthanakosin kingdom was imported foreign coals for daily cooking purposes such as coconut oil, Chinese peas, garlic and onions, flour, rice, salt, tea, white and brown sugar, and wheat (Bradley, 1906). Thailand country is colloquially known as the heavenly country due to its abundance of food and natural resources including various plants of vegetables, herbs, and spices. The unique Thai food is recognition of local traditional knowledge to sell in Thailand for both local and overseas consumption. Many kinds of Thai food are well-known locally in Thailand and spread to Southeast Asia until now still distribution around the world such as tom yum, tom kha, pad Thai, green curry, red curry and massaman curry which that people eat each Thai curry with rice recipes. In the Northeast and Southeast Asia region uses rice as a main ingredient (Koo \& Kim, 2005).

In 1960, the beginning of the international tourism in Thailand was first exposed foreign visitors to Thai food. In 2003 until today, the globalization may enhance access to Thai traditional foods because of changing prices, production practices and eating behaviors, as well as importing some ingredient and exporting vegetables, herbs, and spices and marketing practices. There are any numbers of inexpensive industrially produced foods that are rapid and convenient to eat. Thailand country was heavily influenced by the culture, moral, and religions of India and Chinese culture (Salleh, 2009) until the present that similar to other country in Southeast Asia area likes Cambodia, Laos, Myanmar, and Vietnam.

\section{Traditional Ingredients of Original Curry Paste in Thai Food}

Thailand country possesses a wealth of culture food traditions and architecture that is rich in natural resources of fragrant herbs, spices, plants, and vegetables (Hugh, 2005). The original Thai food is popular with consumers in many countries in Asia especially widespread in Southeast Asia and Japan, Germany, and United States throughout around the world. Many kinds of Thai curries have used been the traditional ingredients process that has shown the technique and preparation method to be unique by mortar and pestle. The important ingredients obtained various fresh herbs and dried materials. For instant, the fresh spices garlic, shallot, galangal, lemongrass, skin of kaffir lime, chili and other fresh herbs and spices through preparation method and cooking process until it smells piercingly aromatic, the layer of taste are finely poised and seasoning finely balanced it is as sophisticated as Thai culture. Thai foods is known for peppery taste fragrant spices and herbs add a component in food, flavor national, and promoting health benefits (Nakornriab \& Puangpronpitag, 2011). The spice is a vital part of food preparation and enhances the aromatic flavor of Thai dish such as Heracleum siamicum Craib. named Ma Laep found in the north and northeastern Thailand (Hedge \& Lamond, 1992). The essential oil from the fruits of Ma laep showed bactericidal and fungicidal activity against five bacterial strains and two fungal strains (Kuljanabhagavad et al., 2011). For the survey Thai food recipes have been reported the most popular and very delicious of taste in six kinds of Thai curry paste selected by order of a dish, gaeng massaman, gaeng khiao wan, tom yum, tom kha (hot and spicy soup with coconut milk), gaeng phet, and gaeng kari (Grove \& Grove, 2010; Kanchanakunjara, 2013).

In addition, Thai people accumulated through many years of the experience and sustainable value creation would surely be to live in equilibrium with the environment season and consumption. This is a reason identity of Thai food for good health benefits. The royal Thai government has been promoting and government policies on food and agriculture for industry kitchen of the world in the year 2003 to 2027. Thailand is the kitchen of the world an origin and growth of the Thai food industry. In recently, the interesting case study of Thai curry paste product of Thailand in different country have been well documented and the traditional local foods have been reported as Thai curry integrated on the menus in South Africa (Njomo, 2012). In particular, all of Thai herbs and spices in traditional curry paste are high vitamin from the green vegetables and phytonutrients that are content secondary metabolites produce. 
The original Thai food cooks use fresh ingredients, including vegetables, herbs and spices, pork, fish, and meat, kaffir lime, galangal, lemongrass, and fresh coriander give the food. It is typically characteristic odor in Thai food, while liberal helpings of fresh chilies add some fire to many dishes with dried chilies such as pad Thai. For other generally seasonings include green and black pepper, coconut cream and milk, and tamarind, which are often added to curries. The popular neutral dishes in Thailand are varieties of the spice of life, one can specially have a different meal options available to every day of the year such as gaeng massaman (rich spicy curry with beef, lamb, pork or chicken), gaeng kari gai (mild yellow curry with chicken), gaeng khiaw waan (sweet green curry with coconut milk and chicken, pork, beef, fish or shrimp), tom yum goong (hot and sour soup with lime juice, lemongrass, kaffir lime leaves, straw mushroom and shrimp), tom kha gai (soup with galangal rhizome, kaffir lime leaves, chicken, and coconut milk), gaeng jeud (soup with vegetables and meat), khao phat (fried rice), khao man gai (sliced boiled chicken over marinated rice), khao na phet (rice with roasted duck), kuay-tiaw nam (soup with rice noodles, product of meat such as pork ball, fish ball, or shrimp ball, and vegetables), laat naa (stir fired rice noodles, slice pork and vegetables in a thick gravy), pad siyu (stir fried rice noodles with slice pork and vegetables), sang kha-yaa maphraow (coconut custard), kluay khaek (fried banana), mamuang khao niaw (ripe mango with sticky or glutinous rice in coconut cream) (Kanchanakunjara, 2008). In the present, condiment processing in Thailand has increased the convenience of cooking type of food with ready to eat (Kosulwat, 2002). They have proved an easy way for general consumer to store and use. Thai people in the central region increased their consumption of sugar and sweeteners more than other regions. Thai people at home, homemade meals are rarely seen and are being replaced by ready-to-cook and ready-to-eat foods bough at local markets, supermarket standalone, food stalls, grocery store, convenience store, supermarkets or big department stores and eaten at home. Interest has also been stimulated for other reasons. Thai curries indigenous knowledge conforms to the international quality standards. Indeed, this research explores the recipes that were developed by using process of indigenous knowledge in produce to standardize and benefits of economic and curries recipe of a care ecology, residence living place, utilize management of herbs and spices. In the previously reported, we reported two kind important traditional Thai curry paste of massaman curry and tom yum that is the first original Thai curry pastes from central Thailand included three important places in Bangkok (Kanchanakunjara et al., 2014b).

\section{History of Massaman Curry Paste and Tom Yum in Thailand}

Initially, we have found the original curries and traditional curry pastes started the development from the Lanna period to close Sukhothai period in the $13^{\text {th }}$ century, which was approximately 700 years. They have been used in a variety ingredient of raw pork, poultry, catching water fish and shellfish, wild vegetable and harvest agricultural vegetable by cut, pounded, smashed or chopped in the method of cooking. Some seasonings were available with chili, pepper, salt, and palm sugar for cooking. Utensils for cooking used as a paddle and mortar made of stone to paste an ingredient. Food container was imported from China. In Thai culture, rice plays the important role of every meal. In that time, Ayutthaya period, Thai people were traded with many nations in Asia and a Western country. Chinese people come to our country had significant influences in Thai cooking. We enlarge our collection of cooking utensils and tools, consequently our cooking techniques expanded from the Chinese. Some curry recipes were using shrimp paste and seasoning with salt and nam pla and many herbs and spices such as galangal, pepper corn, cinnamon, clove, nutmeg, garlic and shallot. It is used as an ingredient for curry paste by crushed and pounded with a pestle and mortar cooking in coconut cream and milk. Types of meat consumption are seafood, fish and kind of shellfish from the river, processing products. In that time, Thonburi period created the first cookbooks printing on record seem to be mainly lists of recipes, preparation method of cooking. Ratthanakosin period, traditional Thai food there are several ethnic indicated that there is a modern purism is delicate to cook. In addition, in the religious ceremony and beliefs came from the ubiquitous royalty food and local folk. The influence foreign food for Thai food mainly comes from China and India. It is derived from the trade relations such as rice, salt, coconut oil, wheat flour, sugar, salted shrimp, onion, garlic and pickles. The most important ingredient is derived from the cultivation of agricultural crops in abundance.

In Thailand, most pastes used the same basic ingredients while their proportions can vary in order to modify the characteristics of classification of traditional curry pastes. The traditional way in the curry paste if some curry paste has dried spices in the recipe needed to medium heat and dry-fried until fragrant, pound or grind until very fine and measured. Using stone pestle and mortar to pound curry paste could be divided into four steps. 1) pounded salt, chili (for dried chili use to remove the seeds and ribs to minimize the heat, soak until soft and minced) and pepper until the chili are reduced to a thick paste. 2) add wet ingredient herb and spices minced such as lemongrass, galangal, kaffir lime skin, coriander root, garlic, and shallot pounding to a smooth paste as possible. 3) add dried spices powder pounding until well mixed. 4) add shrimp paste softly pounding again to form the curry paste 
(Kanchanakunjara et al., 2014a). In the present, the school was set up to teach the children of the nobility and have activities for cooking contest, food business about processed food, semi-instant food and instant food.

Cooking curry started to put coconut cream into a warm wok or large frying pan. Cook slowly in the medium high heat, stirring regularly, until it reduces to a thick and the oil starts to separate out and bubbling. Then add the curry paste and cook to release the fragrance. Use your sense of curry paste smell fragrant aroma to tell when the paste is ready. In addition, the extraction techniques from essential oils contained in spices and herbs and prevent oil being oxidized from the air. The mainly methods of cooking curry are divided into these two methods. To accomplish this, follow the steps below: the first preparation method, 1) add the meat, cook until almost done, season with nam pla and palm sugar, 2) add coconut milk to the boil, 3) add eggplants, pea eggplants and let it simmering point, 4) add kaffir lime leaves, sweet basil, and chilies, 5) simmer until vegetables are softened but still firm and colorful and 6) remove from heat. The second preparation method, 1) add the coconut milk, meat, stirring to incorporate, 2) when the curry sauce comes to a boil, reduce heat to medium or medium-low, until you get a nice simmer and cooked through, 3) add eggplants, pea eggplants, kaffir lime leaves, sweet basil, and chili, 4) simmer until vegetables are softened but still firm and colorful, 5) remove from heat, 6) note that this curry should be a balance of salty, spicy, sweet and sour, plus bitter (the bitter is found in the fresh basil garnish) and 7) serving curry in a bowl with Thai jasmine rice served separately.

\section{Technique Development of Massaman Curry Paste and Tom Yum}

It began from finding vegetables, herb and spices (Raghavan, 2007) such as shallot (Allium ascaonicum L.), garlic (Allium sativum L.), coriander root (Coriandrum sativa L.), pepper (Piper nigrum L.), dried chili (Capsicum frutescens L.), lemongrass (Cymbopogon citrates Stapf.), galangal (Apinia galangal L.), kaffir lime (Citrus hystrix DC.), cumin (Cuminum cyminumi L.), mace and nutmeg (Myristica fragrans Houtt.), cinnamon (Cinnamomum burmanii (Nees \& T. Nees) Blume), star anise (Illicium verum Hooker), Siam cardamom (Amomum krervanh Pierre) and clove (Eugenia caryophyllata Thunberg). They are mainly herbs and spices of traditional curry paste used in massaman curry, green curry, yellow curry, and panaeng curry. The different types of curry were use in some different materials number. There are almost use in types of Thai curry that are very important material in curry and hot and sour soup.

Table 1. Raw materials used in massaman curry and tom yum and developed recipes

\begin{tabular}{l} 
Raw Materials \\
\cline { 2 - 3 } big pepper \\
bird's eye chili \\
cardamom \\
cinnamon \\
clove \\
coriander root \\
coriander fruit \\
cumin fruit \\
galangal \\
garlic \\
kaffir lime leaves \\
lemongrass \\
nutmeg \\
pepper \\
salt \\
shallot \\
shrimp paste \\
star anise \\
Thai chili paste
\end{tabular}

Note: (• Used as an ingredient). 
Thai curry paste shown in Table 1 of the 19 raw materials and 14 raw materials for the original curry paste of massaman curry and 5 raw materials use in tom yum, with cover the main materials of two curry pastes that found in the first reported of this project. One interesting fact to note is that many of the ingredients used in curry paste of massaman curry and tom yum. The herbs and spices use as ingredients were brought from the organic farm. The plants dried the materials with the special machine to protect the favor and aromatic. After that, the herbs and spices dried were used for traditional curry paste, which called Thai curry paste pyramid (Kanchanakunjara et al., 2014). It also was the first kind of curry paste invented by Thai people in Thailand. In this case, it is a very useful for designing products. It made changes in lifestyle and reformed the daily life curry pastes pyramid suitable and convenient for ready to eat of two people, four people, and six people. It could be claim that Thai curry paste pyramid was the original curry paste of organic material from natural and non-chemical ingredient and non-chemical food preservative.

\section{Conclusion}

The conclusion from this study that traditional ingredient and original curry pastes during Sukhothai to Ratthanakosin is significant and worthy of protection and cultural heritage of Thailand. In the Ratthanakosin period, curry pastes preparation could be divided into two sectors of the reigns of Rama I to Rama III and Rama IV to Rama IX. Perhaps the dynamic interplays between tradition and modernity in the construction of the dynasty and society. Considering the culinary arts in Thailand reflects the continued presence due to regional diversity and a royal court and the widely range of ingredients in Thailand. The original curry pastes would produce and reproduce identity that belongs to the sphere and deeply related in a particular place, space, and time, the original curry pastes traditions of a specific area reveal the character. We have just seen that traditional curry paste evolves in relation to its period, environment, and actors. They are an integral part of individual, collective, and territorial identity. We find in rural areas corresponds to the tradition of a whole group of the old Thai style which generates a feeling of belonging to this particular area, interesting in value. All the recipes in the collection of original Thai dishes such as a popular curry and also other curries traditionally processed Thai curry paste products named massaman curry in Thai leagues called gaeng massaman and well known of hot and sour soup in Thai leagues called tom yum have been marginally modified for Western tastes.

\section{Acknowledgments}

Authors would like to thanks Faculty of Culture Science, Mahasarakham University, Thailand and Division of Research Facilitation and Dissemination for their scholarship to T.K. and the Oriental Hotel Apprenticeship Program (OHAP), Suan Dusit International School, and Faculty of Home Economics Technology in Rajamangala University of Technology Krungthep Phranakhon Tai campus for facilitate support. We thank Assist. Prof. Sudaporn Timlerg, Assist. Prof. Dr. Naruemon Nantaragsa, Mr. Vichit Mukura, Ms. Chatchaya Raktakanit, Ms. Amaraporn Wongvak, Mr. Nuttaphong Teeranuutapichit, Mr. Prapassorn Tanopass, Mr. Nakrob Narksuwan, Mr. Narongsak Saisang, Ms. Siri-isaree Boonyakittikowit, Mr. Wisanu Buntam, and Mrs. Wandee Sirithana, Ms. Jetvipa Kanchanakunjara, for their assistance before and during the curry pastes workshop.

\section{References}

Ankri, S., \& Mirelman, D. (1999). Antimicrobial properties of allicin from garlic. Microbes and Infection, 1(2), 125-129.

Bradley, C. B. (1909). The Oldest known writing in Siamese; the inscription of Phra Ram Khamhaeng of Sukhothai, 1293 A.D. Journal of the Siam Society, 6(1), 5-68.

Bradley, D. B. (1906). Poket. Reprint from Dr. Bradley's Bangkok Calendar for 1871. Journal of the Siam Society, $3(1), 17-20$.

Chotechuang, N. (2012). Taste active components in Thai foods: A review of Thai traditional seasonings. Journal of Nutrition \& Food Sciences, S10:004.

Cochrane, J. (Ed.). (2008). Asian tourism: Growth and change. Hungary: Elsevier.

Coedes, G. (1918). Notes critiques sur L'inscription de Rama Khamheng. Journal of the Siam society, 12(1), 1-27.

Coedes, G. (1921). Siamese documents of the seventeenth century. Journal of the Siam Society, 14(2), 7-39.

Douglas, M., Heyes, J., \& Smallfield, B. (2005). Herbs, spices and essential oils Post-harvest operations in developing countries. United Nations Industrial Development Organization, Austria: Institute for Crop and Food Research Inc.UNIDO and FAO.

Faithong, N., Benjakul, S., Phatcharat, S., \& Binsan, W. (2010). Chemical composition and antioxidative activity of Thai traditional fermented shrimp and krill products. Food Chemistry, 119(1), 133-140. 
Frankfurter, O. (1906). Some suggestions for romanizing Siamese. Journal of the Siam Society, 3(2), 52-61.

Gerini, G. E. (1904). On Siamese proverbs and idiomatic expressions. Journal of the Siam Society, 1, 11-168.

Goel, A., Kunnumakkara, A. B., \& Aggarwal, B. B. (2008). Curcumin as "curecumin": from kitchen to clinic. Biochemical Pharmacology, 75(4), 787-809.

Grove, P., \& Grove, C. (2010). The Flavours of history (From corn to chilli to curry): Peter J. Grove.

Hazarika, M. (2006). Neolithic culture of Northeast India: A recent perspective on the origins of pottery and agriculture. Ancient Asia, 1, 25-43.

Hazra, K. L. (1982). History of Theravāda Buddhism in South-East Asia with special reference to India and Ceylon. West Patel Nagar, New Delhi, India: Munshiram Manoharial Publishers Pvt. Ltd.

Hedge, I. C., \& Lamond, J. M. (1992). Umbelliferae (Vol. 5). Bangkok: The Chutima Printing.

Hugh, T. W. T. (2005). Herbs and spices of Thailand. Singapore: Times Editions-Marshall Cavendish.

Jones, N. L., Shabib, S., \& Sherman, P. M. (1997). Capsaicin as an inhibitor of the growth of the gastric pathogen Helicobacter pylori. FEMS Microbiology Letters, 146(2), 227-233.

Kanchanakunjara, T. (2008). The $20^{\text {th }}$ Thai Cooking Demonstration: La Demostracion de la Cocina Tailandesa article. Retrieved from http://www.thaiembassychile.org/index.php?lay=show\&ac=article\&Id=538740388 \&Ntype $=1$.

Kanchanakunjara, T. (2013). Thai curry paste: An application of indigenous knowledge based on a creative economy for exporting. Ph.D., Mahasarakham University, Mahasarakham Province.

Kanchanakunjara, T., Chantachon, S., Koseyayothin, M., \& Kuljanabhagavad, T. (2014a). Research and development of traditional massaman curry paste and tom yum in central Thailand for the Western. Gastronomica, submitted.

Kanchanakunjara, T., Chantachon, S., Koseyayothin, M., \& Kuljanabhagavad, T. (2014b). Use of indigenous knowledge in food processing and preservation of traditional curry paste recipes in central Thailand for global market. African Journal of Indigenous Knowledge Systems, submitted.

Koo, S. J., \& Kim, H. S. (2005). In Cultural foods in the world. Paju: Kyomoonsa.

Kuljanabhagavad, T., Sriubolmas, N., \& Ruangrungsi, N. (2011). Chemical composition, antibacterial and antifungal activities of essential oil from Heracleum siamicum Craib. Pharmaceutical Chemistry Journal, 45(3), 178-182.

Kuljanabhagavad, T., Thongphasuk, P., Thongphasuk, J., \& Wink, M. (2014). Effect of $\gamma$-irradiation on bioactive chemical constituents and antioxidant activity of turmeric (Curcuma longa L.) rhizome. Radiation Physics and Chemistry, submitted.

Kulke, H., \& Rothermund, D. (1998). A History of India (3rd ed.). Routledge, United State: Taylor \& Francis.

Manich, M. L. (1967). History of Laos (Including the history of Lannathai, Chiengmai). Bangkok, Thailand: Chalermnit, 1-2, Erawan Arcade.

Miquel, J., Bernd, A., Sempere, J. M., Díaz-Alperi, J., \& Ramírez, A. (2002). The curcuma antioxidants: pharmacological effects and prospects for future clinical use. A review. Archives of Gerontology and Geriatrics, 34(1), 37-46.

Mouritsen, O. G. (2012). Umami flavour as a means of regulating food intake and improving nutrition and health. Nutrition and Health, 21(1), 56-75.

Nakornriab, M., \& Puangpronpitag, D. (2011). Antioxidant activities and total phenolic contents of Thai curry pastes. International Journal of Applied Chemistry, 7(2), 43-52.

Njomo, L. M. (2012). Satisfying the indigenous food needs of sub-Saharan African immigrants in South Africa: A food consumption behaviour model for South Africa's leading supermarket chains. African Journal of Business Management, 6(25), 7557-7568.

Pelliot, P. (1959). Notes on Marco Polo (Vol. I). Paris, UK: Imprimerie Nationale Librarie Adrien-Maisonneuve.

Prasartkul, P., \& Vapattanawong, P. (2012). Changing Demographics (pp. 10-11). Institute for Population and Social Research, Bangkok, Thailand: Mahidol University. 
Raghavan, S. (2007). Handbook of spices, seasonings, and flavorings (2 ed.). 6000 Broken Sound Parkway NW, Suite 300 Boca Raton, FL, US: CRC Press Taylor \& Francis Group.

Rajadhon, A. (1988). Essays on Thai Folklore (3rd ed.). Bangkok: Thai Inter-Religious Commission for Development \& Sathirakoses Nagapradipa Foundation. Kled Thai Co. and Suksit Siam.

Rajanubhab, D. H. R. H. (1904). The Foundation of Ayuthia. Journal of the Siam Society, 1(1), 7-10.

Rajanubhab, D. H. R. H. (1914-15). The story of the records of Siamese history. Journal of the Siam Society, 11(2), $1-20$.

Salleh, M. H. (2009). Words over borders: Trafficking literatures in Southeast Asia. Asiatic, 3(2), 1-24.

Seah, R., Siripongvutikorn, S., \& Usawakesmanee, W. (2010). Antioxidant and antibacterial properties in Keang-hleung paste and its ingredients. Asian Journal of Food and Agro-Industry, 3(2), 213-220.

Siripongvutikorn, S., Pengseng, N., Ayusuk, S., \& Usawakesmanee, W. (2008). Development of green curry paste marinade for white shrimp (Litopenaeus vannamei). Songklanakarin Journal of Science and Technology, $30(1), 35-40$.

Sirivejkul, N. (2003). Division of Historical Periods: MAC Printing Co., Ltd.

van der Heide, J. H. (1906). The Economical development of Siam during the last half century. Journal of the Siam Society, 3(1), 74-109.

Wei, L. S., \& Wee, W. (2013). Chemical composition and antimicrobial activity of Cymbopogon nardus citronella essential oil against systemic bacteria of aquatic animals. Iranian Journal of Microbiology, 5(2), 147-152.

Wright, M. (1992). Ayudhya and its place in pre-modern Southeast Asia. Journal of the Siam Society, 80(1), 81-86.

Wyatt, D. K. (1974). A Persian mission to Siam in the reign of King Narai. Journal of Siam Society, 62(1), 151-157.

Yoshida, Y. (1998). Umami taste and traditional seasonings. Food Reviews International, 14(2-3), 213-246.

\section{Copyrights}

Copyright for this article is retained by the author(s), with first publication rights granted to the journal.

This is an open-access article distributed under the terms and conditions of the Creative Commons Attribution license (http://creativecommons.org/licenses/by/3.0/). 